\title{
IDENTIFIKASI KEGIATAN PEMBENTUKAN RUANG LUAR RUKO PADA KORIDOR JALAN DI KAWASAN PERUMAHAN SAWOJAJAR KOTA MALANG
}

\author{
Elong Pribadi ${ }^{\star \star}$ ) dan Suning*)
}

\begin{abstract}
Abstrak
Salah satu kebutuhan masyarakat perkotaan adalah tersedianya areal ruang publik (public space) yang dapat dimanfaatkan oleh berbagai kalangan dalam setiap waktu. Kota Malang adalah merupakan kota terbesar kedua di Jawa Timur yang diarahkan sebagai kota pendidikan, pariwisata dan industri, yang sedang mengalami perkembangan yang cukup pesat. Mengamati pertumbuhan ruko di koridor jalan utama di kawasan perumahan Sawojajar belakangan ini memberikan gambaran yang menarik untuk dilakukan penelitian terkait interaksi kegiatan pada ruang luar ruko.

Penelitian ini bertujuan untuk mengidentifikasi jumlah bangunan ruko, tipe ruang luar ruko dan kegiatan pembentuk ruang luar ruko. Analisa dilakukan dengan metode diskriptif kualitatif dan metode analisa pemetaan perilaku (Behavioral Mapping) terhadap kegiatan pembentukan ruang luar ruko hasil analisis menunjukkan bahwa ada keterkaitan antar aktivitas dalam memanfaatkan ruang luar ruko berdasarkan waktu dan bentuk ruang luar ruko, sehingga diketahui bahwa ruang luar ruko di Kawasan Sawojajar didominasi oleh kegiatan pedagang kaki lima, baik tipe bangunan yang bersifat komunal maupun kompleks pertokoan yang mampu mengakomodir kegiatan ruang luar ruko, serta tipe ruang luar ruko semi privat dan publik.
\end{abstract}

Kata Kunci : Ruko, Ruang Luar Ruko, Kegiatan Ruang Luar Ruko, Kota Malang

\section{A. PENDAHULUAN}

Salah satu kebutuhan masyarakat perkotaan adalah tersedianya areal ruang publik (public space) yang dapat dimanfaatkan oleh berbagai kalangan dalam setiap waktu. Maka sejatinya dalam suatu kota hingga tingkat wilayah terkecilnya harus selalu terdapat areal ruang publik untuk mengakomodir kebutuhan masyarakat secara luas. Penataan ruang publik sebagai bagian kawasan kepentingan umum yang terstruktur dan diarahkan untuk estetika perkotaan maupun sebagai ruang aktivitas masyarakat, dimana wujud fisik kawasan kepentingan umum dapat berupa alun-alun, lapangan terbuka, taman kota, jalur pedestrian, areal plaza, lahan parkir dan lainlain.

Kota Malang adalah merupakan kota terbesar kedua di Jawa Timur yang diarahkan sebagai kota pendidikan, pariwisata dan industri, yang sedang mengalami perkembangan yang cukup pesat. Dengan demikian, perkembangan apapun yang terbentuk di Kota Malang, akan menjadi orientasi dan pusat tarikan kegiatan bagi wilayah-wilayah di sekitarnya. Terdiri dari 5 (lima) wilayah administrasi Kecamatan, dengan Kecamatan Klojen diarahkan sebagai pusat pelayanan utama bagi wilayah Kota Malang. Sebagai wilayah dengan fungsi dan peranannya sebagai wilayah perkotaan, maka sebagian besar perkembangan pola pemanfaatan ruang wilayah Kota Malang cukup pesat dengan kecenderungan pertumbuhan kawasan terbangun yang menyebar ke seluruh wilayah.

Mengamati pertumbuhan ruko di koridor jalan utama di kawasan perumahan Sawojajar belakangan ini memberikan gambaran yang menarik untuk dilakukan penelitian terkait kegiatan pada ruang luar ruko. Aktivitas-aktivitas dalam memanfaatkan ruang luar ruko di koridor jalan di kawasan perumahan Sawojajar tentunya memiliki ciri dan perbedaan tersendiri, baik dari segi bentuk pemanfaatan ruangnya, waktu dan intensitasnya, serta pelaku dan interaksi yang terjadi didalamnya.

\section{B. METODOLOGI PENELITIAN}

Tujuan dari penelitian ini adalah untuk mengetahui karakteristik ruko dan ruang luar ruko, kegiatan pembentukan perilaku masyarakat pada ruang luar ruko yang terjadi di Kawasan Perumahan Sawojajar.

\footnotetext{
**) Mahasiswa PWK

*) Dosen PWK

Universitas PGRI Adi Buana Surabaya
} 
Metode pengumpulan data terdiri dari tahapan persiapan dan teknik survey, tahapan persiapan merupakan tahapan awal dalam mempersiapkan segala kebutuhan berupa data-data awal sebagai bahan persiapan survey, sedangkan teknik survey merupakan tahapan pengumpulan data dan informasi yang terkait dengan tema penelitian dimana terdiri dari survey primer dan survey sekuder. Secara luas, observasi atau pengamatan berarti setiap kegiatan untuk melakukan pengukuran. Akan tetapi, observasi atau pengamatan di sini diartikan lebih sempit, yaitu pengamatan dengan menggunakan indera penglihatan yang berarti tidak mengajukan pertanyaan- pertanyaan. Observasi yang dilakukan pada lokasi studi, dengan melakukan pengamatan terhadap beberapa aspek :

- Mendatangi dan melakukan pengamatan secara langsung terhadap semua ruang luar ruko yang terdapat di lokasi penelitian.

- Pencatatan hasil pengamatan untuk kemudian diolah menjadi informasi atau data yang disesuaikan dengan variabel yang telah ditentukan.

- Melakukan dokumentasi dengan media foto atau sketsa sebagai pertimbangan untuk pembuktian kondisi yang ada di lapangan yang nantinya juga digunakan sebagai bahan analisis.

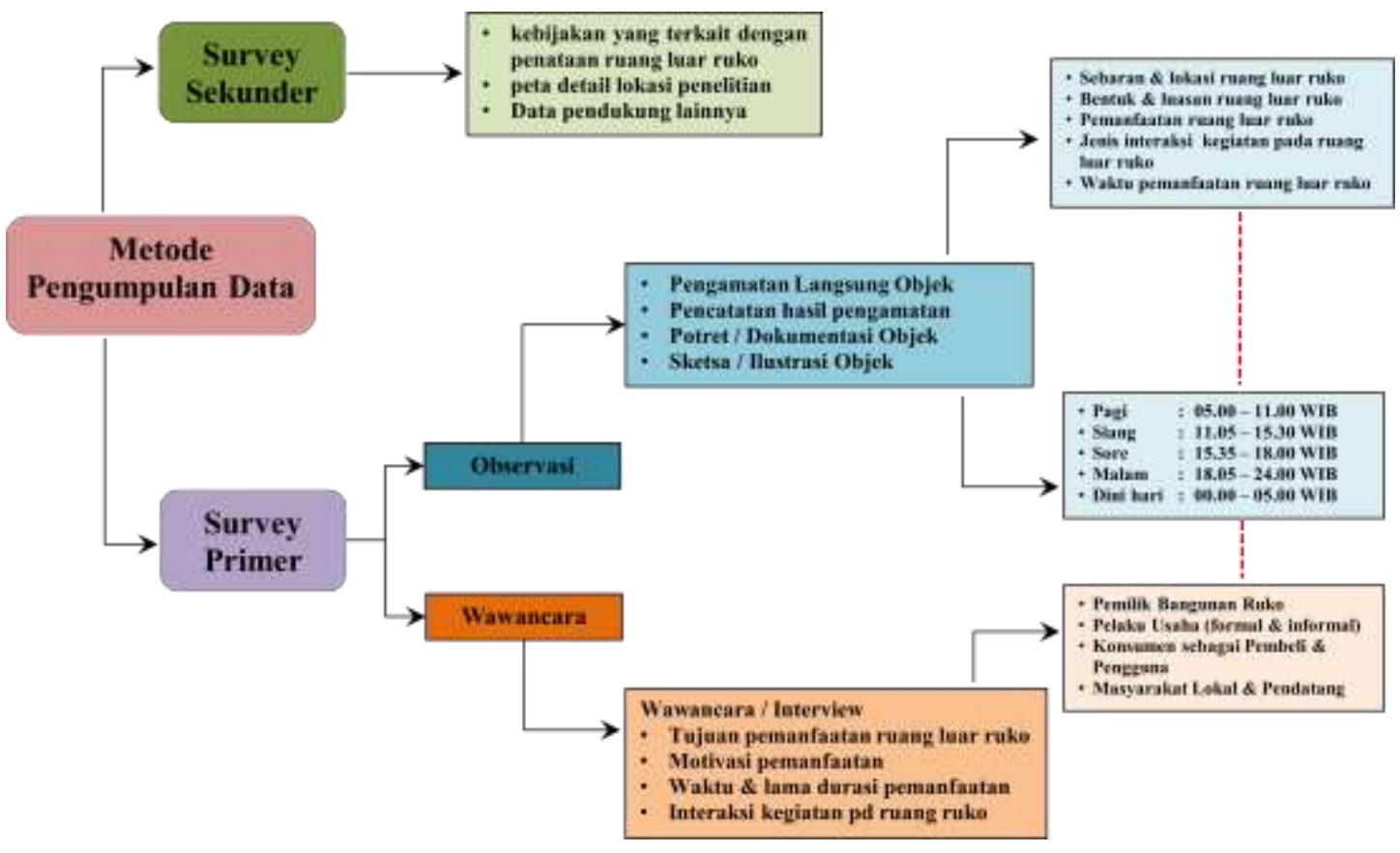

Gambar 1. Metode Pengumpulan Data

\section{HASIL DAN PEMBAHASAN}

Berdasarkan hasil observasi terhadap sebaran keberadaan bangunan ruko yang terdapat pada masing-masing koridor jalan yang merupakan objek amatan utama dalam penelitian, secara keseluruhan jumlah unit ruko yang terdapat dilokasi penelitian yaitu sebanyak 410 unit bangunan ruko. Dengan sebaran tiap-tiap koridor sebagai berikut, koridor Jl. Danau Toba terdapat jumlah sebanyak 191 unit, Jl. Danau Maninjau terdapat jumlah ruko sebanyak 14 unit, Jl. Danau Kerinci Raya terdapat jumlah ruko sebanyak 118 unit, Jl. Danau Bratan terdapat jumlah ruko sebanyak 42 unit dan Jl. Danau Sentani terdapat jumlah ruko sebanyak 45 unit. Untuk lebih jelasnya mengenai persebaran ruko dilokasi penelitian, dapat dilihat pada peta persebaran ruko. 


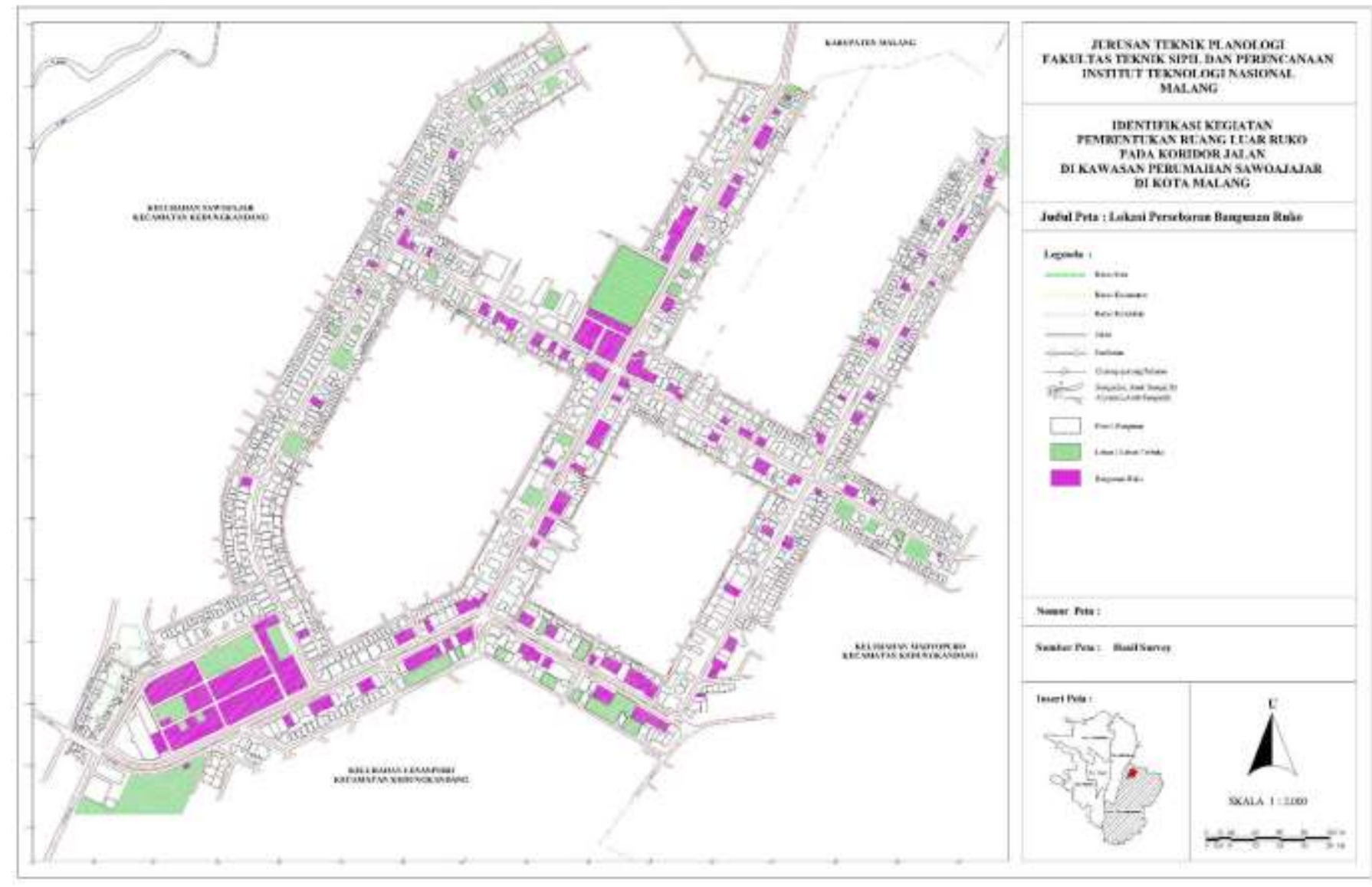

Gambar 2. Identifikasi Kegiatan Pembentukan Ruang Luar Ruko

Ruang Luar Ruko sangat mempengaruhi dan dipengaruhi oleh aktivitas manusia, yang memungkinkan dapat menumbuhkan kegiatan dan aktivitas di dalamnya. Analisa karakteristik pada ruang luar ruko di lokasi penelitian akan menekankan pada pengkajian mengenai analisa sebaran, analisa bentuk-bentuk ruang luar ruko dan analisa luasan ruang luar ruko.

Berdasarkan analisa, maka dapat ditarik suatu kesimpulan akhir mengenai karakteristik pemanfaatan ruang luar ruko di lokasi penelitian. Dalam hal ini, kesimpulan diambil berdasarkan analisa karakteristik pada ruang luar ruko, dan analisa pola pemanfaatan pada ruang luar ruko sehingga menghasilkan tipologi ruang luar ruko. Hasil kesimpulan dari analisa yang telah dilakukan di atas, diketahui bahwa yang mempengaruhi adanya kegiatan pembentukan ruang luar ruko adalah terdapatnya bangunan ruko, memiliki tipe ruang luar ruko yang semi privat dan publik, luasan ruang luar ruko mencukupi untuk menampung berbagai kegiatan, dan berlangsungnya kegiatan yang dilakukan oleh masyarakat.

Tipologi ruang luar ruko di Kawasan Sawojajar berdasarkan tipe bangunan ruko, bentuk ruang luar ruko, luasan ruang luar ruko, dan karakteristik kegiatan. Tipologi kegiatan pembentukan ruang luar ruko yang dihasilkan dari penelitian ini dibedakan menjadi 2 (dua) tipologi dengan karakteristik sebagai berikut :

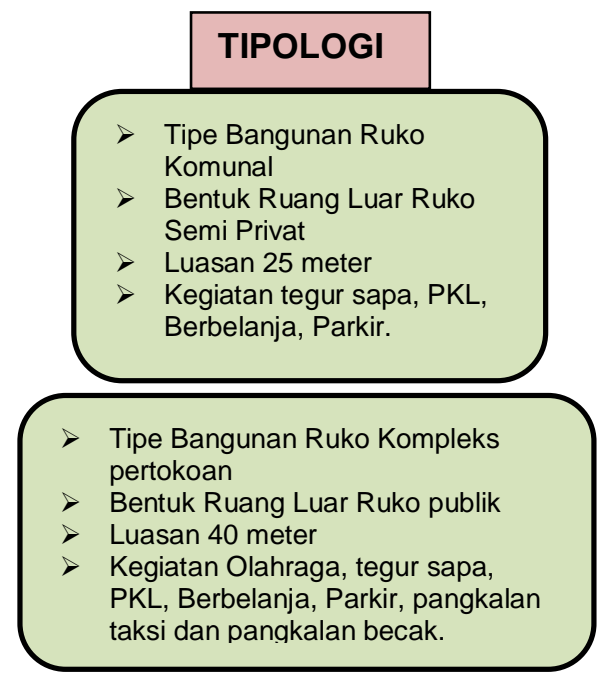




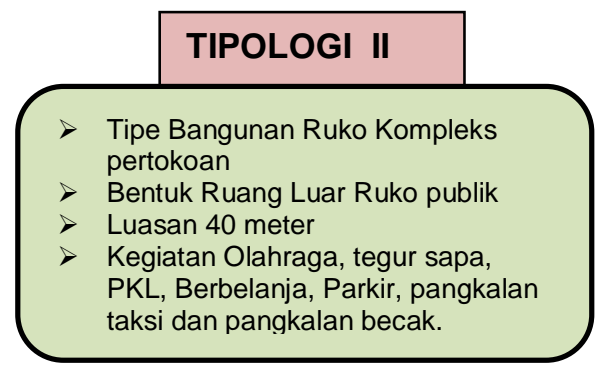

Ruang luar ruko sebagai bagian dari ruang terbuka, tentunya pemanfaatannya dapat dipergunakan oleh publik, dapat mengakomodir kegiatan sosial yang ada pada ruang publik tersebut (responsive), dapat menerima kehadiran berbagai lapisan masyarakat, serta memberi kesempatan untuk bermacam-macam kegiatan (multifungsi).

Konsep pemanfaatan ruang luar ruko di kawasan sawojajar khususnya yang termasuk dalam wilayah studi berdasarkan atas analisis yang telah dilakukan, maka konsep ruang luar ruko yang akan dikembangkan dalam lokasi studi adalah konsep pemanfaatan ruang ruko berdasarkan waktu. untuk selanjutnya akan dijabarkan sebagai berikut.

Tipologi Ruang Luar Semi Privat

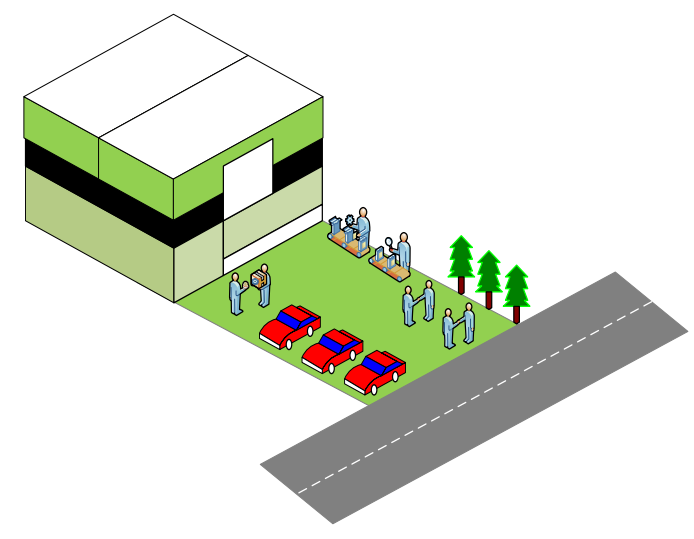

Keterangan :

Berdasarkan gambaran tipologi tersebut, ruang luar ruko semi privat pada Kawasan Sawojajar dapat dimanfaatkan untuk beberapa aktivitas namun jumlah dan ruang aktivitasnya disesuaikan oleh luasan ruang luar ruko.
Tipologi Ruang Luar Publik

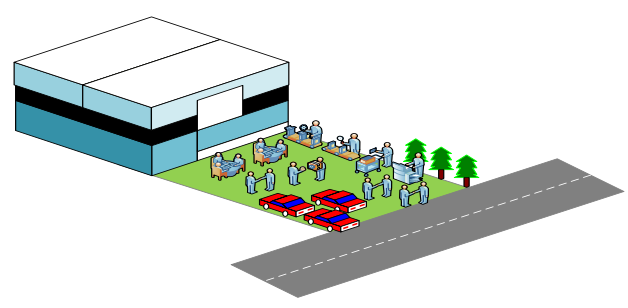

Keterangan :

Berdasarkan gambaran tipologi tersebut, ruang luar ruko publik pada Kawasan Sawojajar dapat dimanfaatkan untuk semua kegiatan karena memiliki luasan yang sesuai untuk berlangsungnya kegiatan.

\section{KESIMPULAN DAN REKOMENDASI \\ a. Kesimpulan}

Berdasarkan hasil analisa dan pembahasan sebelumnya, maka dapat disimpulkan sebagai berikut :

1. Berdasarkan analisa karakteristik pada ruang luar ruko, dan analisa pola pemanfaatan pada ruang luar ruko,maka menghasilkan tipologi ruang luar ruko.

2. Berdasarkan analisa pembentukan ruang luar ruko, maka menghasilkan

a. Bangunan ruko yang memiliki tipe ruang luar ruko semi privat dan publik.

b. Luasan ruang luar ruko yang mencukupi untuk menampung berbagai kegiatan.

\section{b. Rekomendasi}

Berdasarkan kesimpulan yang telah dipaparkan diatas, maka rekomendasi yang dapat diberikan dalam penelitian ini adalah :

1. Perlunya pemanfaatan ruang terbuka sebagai muara yang mampu memberikan adanya pengawasan pada koridor jalan di kawasan perumahan.

2. Perlu adanya pengaturan aksesibilitas simpul keluar-masuk dengan dimensi ruang yang orientatif secara visual menghindari enclosure space yang terlalu kuat.

3. Perlu adanya pengembangan sistem pengamanan terpadu pada koridor jalan di kawasan perumahan yang mampu mengurangi tindak kriminal 


\section{DAFTAR PUSTAKA}

Anwar. Analisis Model Setting Ruang Komunal Sebagai Sarana Interaksi Sosial Penghuni Rumah Susun. Tesis Universitas Diponegoro. Semarang. 1998.

Ari Rasano, Paulus. Pembentukan Urban Spatio-Temporal Places Berdasarkan Perilaku Masyarakat, Skripsi : Jurusan Teknik Planologi ITN Malang. Malang, 2008.

Ashihara, Yoshinobu, "Merancang Ruang Luar" terjemahan dari judul asli ; Exterior Design in Architecture oleh Sugeng Gunadi, Surabaya, 1983.

Bakri, Masykuri, Metodologi Penelitian Kualitatif - Tinjaun Teoritis dan Praktis, Lembaga Penelitian Universitas Malang-Visipres, Surabaya, 2003.

Darmawan, Edy, Teori dan Kajian Ruang Publik Kota, BP UNDIP, Semarang, 2003.

Dr. Azhar Susanto, Mbus, dalam bukunya yang berjudul "Sistem Informasi Manajemen Konsep dan Pengembangannya (2004:51)"

Hanifah. Fungsi Ruang Luar Akibat Perubahan Fungsi Bangunan di Koridor Jalan Diponegoro Salatiga. Tesis : Magister Teknik Aristektur Universitas Diponegoro. Semarang, 2003.

Kharismawan, Rabbani. Model Penataan Ruang Luar Ruko Sebagai Upaya Peningkatan Vitalitas Kawasan di Jalan Klampis Jaya Surabaya. ITS Surabaya. 2010

Wahyuasih, Christine. Masalah dan Dilema Perkembangan Ruko Dalam Arsitektur Lingkungan Perkotaan dan Permukiman. Jakarta.

Yunus, Hadi Sabari, Struktur Tata Ruang kota, Pustaka Pelajar, Yogyakarta, 2000. 